Jurnal Inovatif Ilmu Pendidikan Vol. 1 No. 2, (2019) HIm. 123-136

http://jurnal.fkip.unila.ac.id/index.php/JIIP/index

JURNAL INOVATIF ILMU PENDIDIKAN

Email : inovatif.ip@fkip.unila.ac.id

\title{
Analisis Kesulitan Guru Pembimbing dalam Menguasai Konsep dan Praksis Assesment
}

\author{
Citra Abriani Maharani, Muswardi Rosra, Yusmansyah, \\ Diah Utaminingsih \\ Bimbingan dan Konseling, Universitas Lampung \\ Jln Prof. Dr. Soemantri Brojonegoro No. 1 Bandar Lampung 14145 \\ E-mail: citra.abriani@ fkip.unila.ac.id
}

\section{Article Info \\ Received April 2019 \\ Accepted September 2019 \\ Published Oktober 2019}

\section{Keywords:}

counselor competence, assessment, mastery of concept and prescriptive assessment, teacher guidance and counseling

\begin{abstract}
This research aimed to determine the level of difficulty of the Supervising Teacher in Mastering the Concept and Praxis of Assessment to Understand the Conditions, Needs, and Problems of the Counselee. This research used survey research methods with descriptive quantitative research. The population of the research was 160 guidance and counseling teachers who were taken by using proportional sampling techniques from each regional representative, so that 50 teachers of guidance and counseling were obtained. The data collection is collected through understanding tests. The data analysis is used descriptive quantitative analysis. The results of the study showed that the Level of Teacher Difficulties in Mastering the Concept and Praxis of Assessment to Understand the Conditions, Needs, and Problems of the counselees in the very low category with a percentage of $44 \%$. This is supported by the results of the respondents' justification analysis that the level of understanding of the concepts and assessment praxis in guidance and counseling teachers in schools is in the moderate category with only $16 \%$.
\end{abstract}

\begin{abstract}
Abstrak : Penelitian ini bertujuan untuk mengetahui tingkat kesulitan Guru Pembimbing Dalam Menguasai Konsep dan Praksis Assesment Untuk Memahami Kondisi, Kebutuhan, Dan Masalah Konseli. Penelitian ini menggunakan metode penelitian survey dengan jenis penelitian kuantitatif deskriptif. Populasi penelitian sejumlah 160 guru bimbingan dan konseling yang diambil menggunakan teknik proportional sampling dari masing-masing perwakilan daerah, sehingga diperoleh 50 guru bimbingan dan konseling. Pengumpulan data dikumpulkan melalui tes pemahaman. Analisis data menggunakan analisis kuantitatif deskriptif. Hasil penelitian menunjukkan bahwa Tingkat Kesulitan Guru Pembimbing Dalam Menguasai Konsep dan Praksis Assesment Untuk Memahami Kondisi, Kebutuhan, Dan Masalah Konseli dalam kategori sangat rendah dengan presentase $44 \%$. Hal ini didukung dengan hasil analisis jawaban pembenaran responden bahwa tingkat pemahaman teradap konsep dan praksis asesmen pada guru bimbingan dan konseling di sekolah dalam kategori sedang hanya $16 \%$.
\end{abstract}

Kata kunci: kompetensi konselor, assessment, penguasaan konsep dan praksis asesmen, guru bimbingan dan konseling.

(C2019 Jurusan Ilmu Pendidikan, FKIP Universitas Lampung p-ISSN (Media Cetak) 2656-8527 


\section{PENDAHULUAN}

Profesi Konselor merupakan salah satu profesi dari kualifikasi pendidik dalam sistem pendidikan nasional yang setara dengan guru, pamong, tutor, fasilitator dan instruktur. Hal ini ditegaskan dalam UU RI No. 20 Tahun 2003 Pasal 1 Ayat 6. Walaupun memiliki kedudukan yang sejajar, namun masingmasing kualifikasi pendidik memiliki keunikan pada ruang lingkup pekerjanya.

Secara khusus kualifikasi kinerja guru BK secara profesional sudah ditentukan oleh standar kualifikasi akademik dan kompetensi, serta kesejahteraan. Penetapan standar kualifikasi akademik dan kompetensi terkait dengan Permendiknas Nomor 27 Tahun 2008 tentang Standar Kualifikasi Akademik dan Kompetensi Konselor (SKAKK) Pasal 1 Ayat 1 yang menyebutkan bahwa untuk dapat diangkat sebagai konselor, seseorang wajib memenuhi standar kualifikasi akademik dan kompetensi konselor yang berlaku secara nasional. Sedangkan kesejahteraan guru BK terkait dengan tunjangan yang diberikan kepada konselor yang telah bersertifikasi. Kesejahteraan yang memadai akan mendorong, memotivasi kepada guru BK agar melakukan peran dan tugasnya secara professional secara sungguh sungguh.

Kompetensi konselor Indonesia yang telah disusun dan disiapkan oleh ABKIN dan tertuang dalam Naskah Akademik tahun 2007, didalmanya menuntut para konselor sekolah agar dapat melaksanakan kegiatan pelayanan bimbingan dan konseling yang memandirikan peserta didik dalam hal ini konseli. Untuk menjawab adanya tantangan tersebut maka para pemilik profesi konselor dihadapkan pada bagaimana memahami setiap peserta didik secara mendalam. Pemahaman terhadap peserta didik secara mendalam diawali dengan kegiatan asesmen. Penguasaan konselor sekolah terhadap konsep dan praksis asesmen dalam memahami kondisi, kebutuhan dan masalah konseli menjadi mutlak diperlukan.

Pada praktik pelayanan konseling berbasis need assesmen di lapangan, masih belum mencapai harapan sebagaimana yang seharusnya. Berdasarkan pada penelitian Asrori (1990) mengungkapkan bahwa kinerja guru pembimbing di lapangan masih tergolong rendah. Sejalan dengan penelitian yang diungkapkan 
oleh Supriadi (1990) menjelaskan bahwa orangtua siswa merasa belum mendapatkan pelayanan guru pembimbing yang profesional.

Menurut Ilfiandra, dkk (dalam Suhendi, 2008) menginformasikan bahwa kinerja guru pembimbing dalam mengimplementasikan pelayanan bimbingan dan konseling masih dalam kategori belum memuaskan. Kondisi ini menjelaskan bahwa adanya keterbatasan bahkan kesulitan pada guru pembimbing dalam menguasai konsep dan praksis penilaian (assessment) untuk memahami kondisi, kebutuhan, dan masalah konseli.

Berdasarkan paparan di atas, maka penelitian ini bertujuan secara deskriptif untuk menganalisis tingkat kesulitan guru pembimbing dalam menguasai konsep dan praksis assesmen untuk memahami kondisi, kebutuhan, dan masalah konseli, sehingga dapat mengetahui dengan jelas apa yang membuat konselor sulit mengaplikasikan pelayanan BK berdasarkan need assesment.

\section{Teori Kompetensi Konselor}

Menurut Permendiknas No. 27 tahun 2008 tentang SKAKK (Standar Kualifikasi Akademik dan Kompetensi Konselor), dijabarkan bahwa Kompetensi profesional merupakan penguasaan kiat penyelenggaraan bimbingan dan konseling yang memandirikan, yang ditumbuhkan serta diasah melalui latihan menerapkan kompetensi akademik yang telah diperoleh dalam konteks otentik Pendidikan Profesi Konselor yang berorientasi pada pengalaman dan kemampuan praktik lapangan, dan tamatannya memperoleh sertifikasi profesi bimbingan dan konseling dengan gelar profesi Konselor, disingkat Kons.

Berdasarkan SKAKK (Standar Kualifikasi Akademik dan Kompetensi Konselor) dijelaskan bahwa ada 4 ranah yang mesti dikuasai oleh guru Bimbingan dan Konseling/Konselor sekolah, yaitu:

1. Kompetensi pedagogik

2. Kompetensi kepribadian

3. Kompetensi sosial, dan

4. Kompetensi profesional.

empat ranah kompetensi tersebut merupakan dasar bagi Penilaian Kinerja Guru Bimbingan dan Konseling/Konselor sekolah. 
Berdasarkan ekspektasi kinerja antara kinerja Guru Bimbingan dan Konseling/Konselor dengan kinerja guru mata pelajaran. Maka pada Guru mata pelajaran nampak lebih fokus dalam penguasaan ranah kompetensi pedagogik, sedangkan Guru Bimbingan dan Konseling/Konselor lebih fokus pada penguasaan ranah kompetensi profesional.

Secara utuh kompetensi konselor terbagi atas dua komponen yang terlihat berbeda namun tetap terintegrasi dalam praksis sehingga tetap tidak dapat dipisahkan yaitu dari area kompetensi akademik dan kompetensi profesional. Kompetensi tersebut dijabarkan seperti tertera pada gambar berikut:

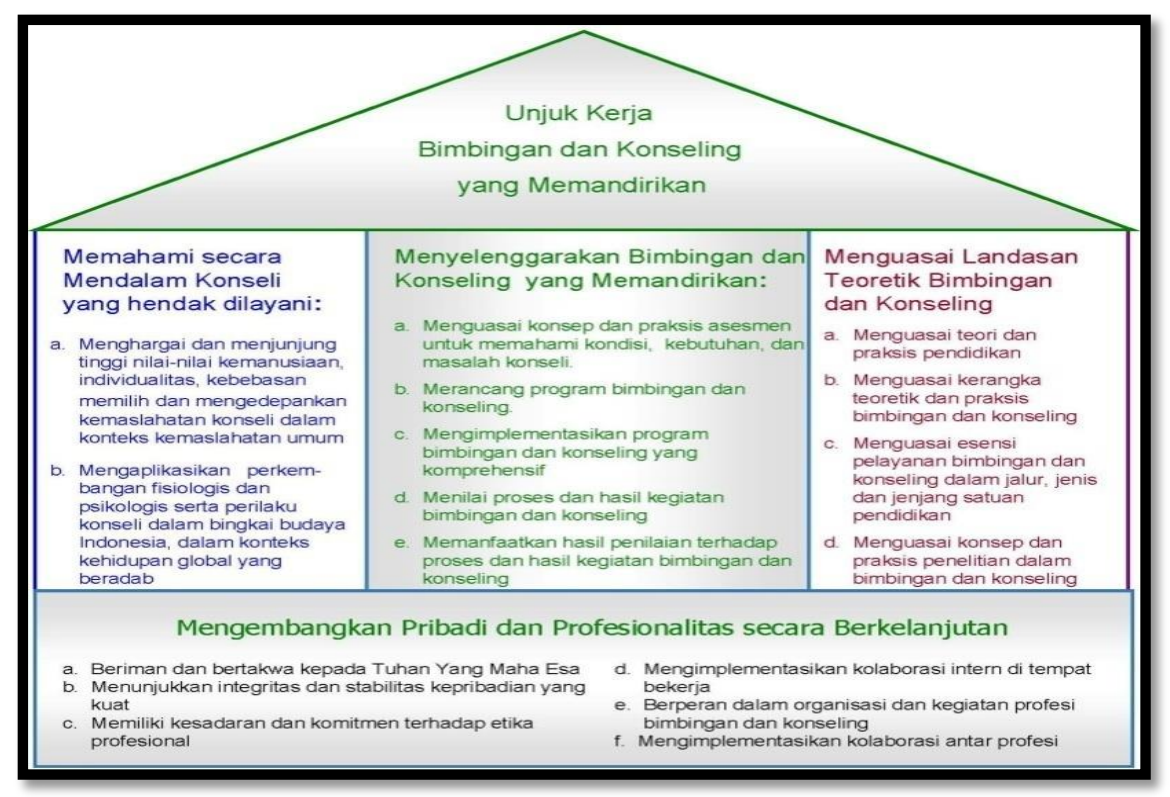

Gambar 1. Kompetensi Konselor (Yusuf, 2009)

\section{Teori Assesmen}

Sebelum memberikan pelayanan konseling, hal yang perlu dilakukan adalah melakukan assessmen, karena berdasarkan data hasil assesment yang memadai dapat menjadi dasar atau acuan untuk melakukan bimbingan dan konseling yang efektif dan efisien dalam rangka mencapai tujuan yang diharapkan.

Asssesmen merupakan suatu penilaian terhadap individu yang berguna dalam memberikan pelayanan bimbingan dan konseling, sehingga sesuai dengan apa yang kebutuhan, kondisi, dan yang menjadi masalah bagi konseli. Pemahaman akan diri konseli menjadi lebih baik, jika didasarkan pada keterangan tentang diri 
yang jelas, akurat dan dipercaya, yaitu data yang berdasarkan pada instrumen hasil assesmen baik dalam bentuk tes maupun non tes.

Menurut Cronbach (1984) penggunaan tes bertujuan agar dapat memajukan pemahaman diri. Disamping itu penggunaan tes juga dimaksudkan untuk klasifikasi, evaluasi dan modifikasi program atau perlakuan, dan penyelidikan ilmiah. Asesmen ialah proses untuk mengumpulkan, menginterpretasikan, dan mensintesiskan informasi dengan tujuan untuk membuat keputusan. Kegiatan assesmen juga diartikan kegiatan pengukuran yang dilengkapi dengan observasi. Assesmen "Suatu penilaian yang komprehensif dan melibatkan anggota tim untuk mengetahui kelemahan dan kekuatan yang mana hasil keputusannya dapat digunakan untuk layanan pendidikan yang dibutuhkan anak sebagai dasar untuk menyusun suatu rancangan pembelajaran”.

Lidz (2003) menjelaskan bahwa tujuan assesmen adalah untuk dapat melihat kondisi anak saat itu. Sumardi \& Sunaryo (2006), secara detail menyebutkan tujuan melakukan assesmen sebagai berikut :

1. Memperoleh data yang relevan, objektif, akurat dan komprehensif tentang kondisi anak saat ini.

2. Mengetahui profil anak secara utuh terutama permasalahan dan hambatan belajar yang dihadapi, potensi yang dimiliki, kebutuhankebutuhan khususnya, serta daya dukung lingkungan yang dibutuhkan anak.

3. Menentukan layanan yang dibutuhkan dalam rangka memenuhi kebutuhankebutuhan khususnya dan memonitor kemampuannya.

\section{Penguasaan Konsep dan praksis asesmen untuk memahami kondisi, kebutuhan, dan masalah konseli}

Dalam hal praksis asesmen, guru pembimbing diharapkan mampu memahami dan mampu mendeskripsikan hakikat asesmen sebagai landasan dalam menyelenggarakan pelayanan konseling, dengan memilih teknik penilaian yang sesuai dengan kebutuhan pelayanan bimbingan dan konseling, menyusun dan mengembangkan instrumen penilaian untuk keperluan bimbingan dan konseling, mengadministrasikan asesmen untuk mengungkapkan masalahmasalah peserta didik, memilih dan mengadministrasikan teknik penilaian pengungkapan 
kemampuan dasar dan kecenderungan pribadi peserta didik, memilih dan mengadministrasikan instrumen untuk mengungkapkan kondisi aktual peserta didik berkaitan dengan lingkungan, mengakses data dokumentasi tentang peserta didik dalam pelayanan bimbingan dan konseling, menggunakan hasil penilaian dalam pelayanan bimbingan dan konseling dengan tepat, menampilkan tanggung jawab profesional dalam praktik penilaian

Adapun indikator seorang guru pembimbing dikatakan mampu untuk menguasai konsep dan praksis asesmen untuk memahami kondisi, kebutuhan, dan masalah konseli adalah sebagai berikut: 1) Menguasai hakikat asesmen, 2) Memilih teknik asesmen, sesuai dengan kebutuhan pelayanan bimbingan dan konseling, 3) Menyusun dan mengembangkan instrumen asesmen untuk keperluan bimbingan dan konseling, 4) Mengadministrasikan asesmen untuk mengungkapkan masalahmasalah konseli, 5) Memilih dan mengadministrasikan teknik asesmen pengungkapan kemampuan dasar dan kecenderungan pribadi konseli, 6) Memilih dan mengadministrasikan instrumen untuk mengungkapkan kondisi aktual konseli berkaitan dengan lingkungan, 7) Mengakses data dokumentasi tentang konseli dalam pelayanan bimbingan dan konseling, 8) Menggunakan hasil asesmen dalam pelayanan bimbingan dan konseling dengan tepat, 9) Menampilkan tanggung jawab profesional dalam praktik asesmen.

\section{METODE}

Penelitian yang digunakan dalam penelitian ini adalah menggunakan jenis penelitian kuantitatif deskriptif dengan metode penelitian survey. Subjek penelitian ini adalah guru bimbingan dan konseling di Provinsi Lampung yang dilakukan dengan teknik Proportional Sampling sehingga diperoleh 17 sekolah yang tersebar di beberapa wilayah. Jumlah guru bimbingan dan konseling dari 17 sekolah ini adalah 50 guru bimbingan dan konseling.

\section{HASIL DAN PEMBAHASAN}

Penelitian ini dilaksanakan di 13 (tiga belas) Sekolah baik tingkat Menengah Pertama (SMP) maupun ditingkat Menengah Atas (SMA dan SMK) Negeri dan Swasta di Provinsi Lampung dan mengambil subjek penelitian 
sebanyak 50 guru bimbingan dan konseling. Kegiatan pengumpulan data dalam penelitian ini dilakukan pada tanggal 07 Oktober 2017. Subjek penelitian adalah guru bimbingan dan konseling di sekolah yang tersebar di Provinsi Lampung, sebanyak 50 orang guru bimbingan dan konseling.

Berdasarkan hasil analisis data diketahui tentang penguasaan Guru BK dalam menguasai konsep dan praksis assesmen bimbingan dan konseling adalah sebagai berikut:

\section{Menguasai hakikat asesmen}

Berdasarkan hasil analisis diketahui bahwa tingkat pemahaman guru BK dalam menguasai hakikat assessment sebesar 20\% untuk kategori tinggi, $8 \%$ untuk kategori sedang, 24\% untuk kategori rendah, dan $48 \%$ untuk kategori sangat rendah. Dari data yang diperoleh maka dapt disimpulakan bahwa pengauasaan Guru BK mengenai konsep assessment tergolong sangat rendah.

Memilih teknik asesmen, sesuai dengan kebutuhan pelayanan bimbingan dan konseling.

Berdasarkan hasil analisis diketahui bahwa tingkat pemahaman guru BK dalam memilih teknik asesmen, sesuai dengan kebutuhan pelayanan bimbingan dan konseling sebesar 24\% untuk kategori tinggi, 14\% untuk kategori sedang, $22 \%$ untuk kategori rendah, dan $40 \%$ untuk kategori sangat rendah. Hasil analasisi data menginformasikan bahwa kemampuan Guru BK dalam memilih teknik asessmen untuk melakukan pelayanan konseling tergolong sangat rendah.

Memilih teknik asesmen, sesuai dengan kebutuhan pelayanan bimbingan dan konseling.

Berdasarkan hasil analisis diketahui bahwa tingkat pemahaman guru BK dalam Menyusun dan mengembangkan instrumen asesmen untuk keperluan bimbingan dan konseling sebesar 10\% untuk kategori tinggi, 16\% untuk kategori sedang, 24\% untuk kategori rendah, dan 50\% untuk kategori sangat rendah. Kemampuan Guru BK dalam memilih teknik asesmen sesuai dengan kebutuhan pelayanan konseling masuk dalam kategori sangat rendah. 


\section{Mengadministrasikan asesmen untuk mengungkapkan masalah-masalah konseli}

Berdasarkan hasil analisis diketahui bahwa tingkat pemahaman guru BK dalam Mengadministrasikan asesmen untuk mengungkapkan masalah-masalah konseli sebesar $44 \%$ untuk kategori tinggi, 6\% untuk kategori sedang, 18\% untuk kategori rendah, dan 32\% untuk kategori sangat rendah.

\section{Memilih dan mengadministrasikan teknik asesmen pengungkapan} kemampuan dasar dan kecenderungan pribadi konseli

Berdasarkan hasil analisis diketahui bahwa tingkat pemahaman guru BK dalam Memilih dan mengadministrasikan teknik asesmen pengungkapan kemampuan dasar dan kecenderungan pribadi konseli sebesar 38\% untuk kategori tinggi, 12\% untuk kategori sedang, 10\% untuk kategori rendah, dan $40 \%$ untuk kategori sangat rendah. Kemampuan Guru BK dalam memilih dan mengadmiistrasikan teknik assessment untuk mengungkap kemampuan dasar dan kecenderungan pribadi konseli masih berada dalam kategori rendah.

\section{Memilih dan mengadministrasikan instrumen untuk mengungkapkan kondisi aktual konseli berkaitan dengan lingkungan}

Berdasarkan hasil analisis diketahui bahwa tingkat pemahaman guru BK dalam Memilih dan mengadministrasikan instrumen untuk mengungkapkan kondisi aktual konseli berkaitan dengan lingkungan sebesar $40 \%$ untuk kategori tinggi, 14\% untuk kategori sedang, 10\% untuk kategori rendah, dan 36\% untuk kategori sangat rendah.

\section{Mengakses data dokumentasi tentang konseli dalam pelayanan bimbingan dan konseling}

Berdasarkan hasil analisis diketahui bahwa tingkat pemahaman guru BK dalam Mengakses data dokumentasi tentang konseli dalam pelayanan bimbingan dan konseling sebesar 34\% untuk kategori tinggi, 6\% untuk kategori sedang, 14\% untuk kategori rendah, dan $46 \%$ untuk kategori sangat rendah. 


\section{Menggunakan hasil asesmen dalam pelayanan bimbingan dan konseling dengan tepat}

Berdasarkan hasil analisis diketahui bahwa tingkat pemahaman guru BK dalam Menggunakan hasil asesmen dalam pelayanan bimbingan dan konseling dengan tepat sebesar 32\% untuk kategori tinggi, 10\% untuk kategori sedang, $8 \%$ untuk kategori rendah, dan 50\% untuk kategori sangat rendah.

\section{Menampilkan tanggung jawab profesional dalam praktik asesmen}

Berdasarkan hasil analisis diketahui bahwa tingkat pemahaman guru BK dalam Menggunakan hasil asesmen dalam pelayanan bimbingan dan konseling dengan tepat sebesar 28\% untuk kategori tinggi, 10\% untuk kategori sedang, $12 \%$ untuk kategori rendah, dan 50\% untuk kategori sangat rendah.

Tabel 1. Pemahaman Terhadap Konsep Dan Praksis Assesmen Secara Keseluruhan

\begin{tabular}{|c|c|c|c|c|c|c|c|c|c|}
\hline \multirow[t]{2}{*}{ No } & \multirow[t]{2}{*}{ Aspek Yang Dianalisis } & \multicolumn{4}{|c|}{ Frekuensi } & \multicolumn{4}{|c|}{ Persentase } \\
\hline & & $\mathbf{T}$ & $\mathbf{S}$ & $\mathbf{R}$ & SR & $\mathbf{T}$ & $\mathbf{S}$ & $\mathbf{R}$ & SR \\
\hline 1. & Menguasai hakikat asesmen & 10 & 4 & 12 & 24 & 20 & 8 & 24 & 48 \\
\hline 2. & $\begin{array}{l}\text { Memilih teknik asesmen, sesuai } \\
\text { dengan kebutuhan pelayanan } \\
\text { bimbingan dan konseling }\end{array}$ & 12 & 7 & 11 & 20 & 24 & 14 & 22 & 40 \\
\hline 3. & $\begin{array}{l}\text { Menyusun dan mengembangkan } \\
\text { instrumen asesmen untuk } \\
\text { keperluan bimbingan dan } \\
\text { konseling }\end{array}$ & 5 & 8 & 12 & 25 & 10 & 16 & 24 & 50 \\
\hline 4. & $\begin{array}{l}\text { Mengadministrasikan asesmen } \\
\text { untuk mengungkapkan } \\
\text { masalah-masalah konseli }\end{array}$ & 22 & 3 & 9 & 16 & 44 & 6 & 18 & 32 \\
\hline 5. & $\begin{array}{l}\text { Memilih dan } \\
\text { mengadministrasikan teknik } \\
\text { asesmen pengungkapan } \\
\text { kemampuan dasar dan } \\
\text { kecenderungan pribadi konseli }\end{array}$ & 19 & 6 & 5 & 20 & 38 & 12 & 10 & 40 \\
\hline 6. & $\begin{array}{l}\text { Memilih dan } \\
\text { mengadministrasikan instrumen } \\
\text { untuk mengungkapkan kondisi } \\
\text { aktual konseli berkaitan dengan } \\
\text { lingkungan }\end{array}$ & 20 & 7 & 5 & 18 & 40 & 14 & 10 & 36 \\
\hline 7. & $\begin{array}{l}\text { Mengakses data dokumentasi } \\
\text { tentang konseli dalam pelayanan } \\
\text { bimbingan dan konseling }\end{array}$ & 17 & 3 & 7 & 23 & 34 & 6 & 14 & 46 \\
\hline
\end{tabular}




\begin{tabular}{|c|c|c|c|c|c|c|c|c|c|}
\hline 8. & $\begin{array}{l}\text { Menggunakan hasil asesmen } \\
\text { dalam pelayanan bimbingan dan } \\
\text { konseling dengan tepat }\end{array}$ & 16 & 5 & 4 & 25 & 32 & 10 & 8 & 50 \\
\hline 9. & $\begin{array}{l}\text { Menampilkan tanggung jawab } \\
\text { profesional dalam praktik } \\
\text { asesmen }\end{array}$ & 14 & 5 & 6 & 25 & 28 & 10 & 12 & 50 \\
\hline 10. & $\begin{array}{l}\text { Pemahaman terhadap konsep dan } \\
\text { praksis assesmen }\end{array}$ & 15 & 5 & 8 & 22 & 30 & 10 & 16 & 44 \\
\hline
\end{tabular}

Dari penjabaran data pada tabel 1 diketahui bahwa hampir sebagaian besar Guru BK yang tersebar di berbagai provinsi di lampung mengalami kesulitan di setiap komponen. Hal ini diperjelas kembali dengan data dalam gambar 2 berikut ini:

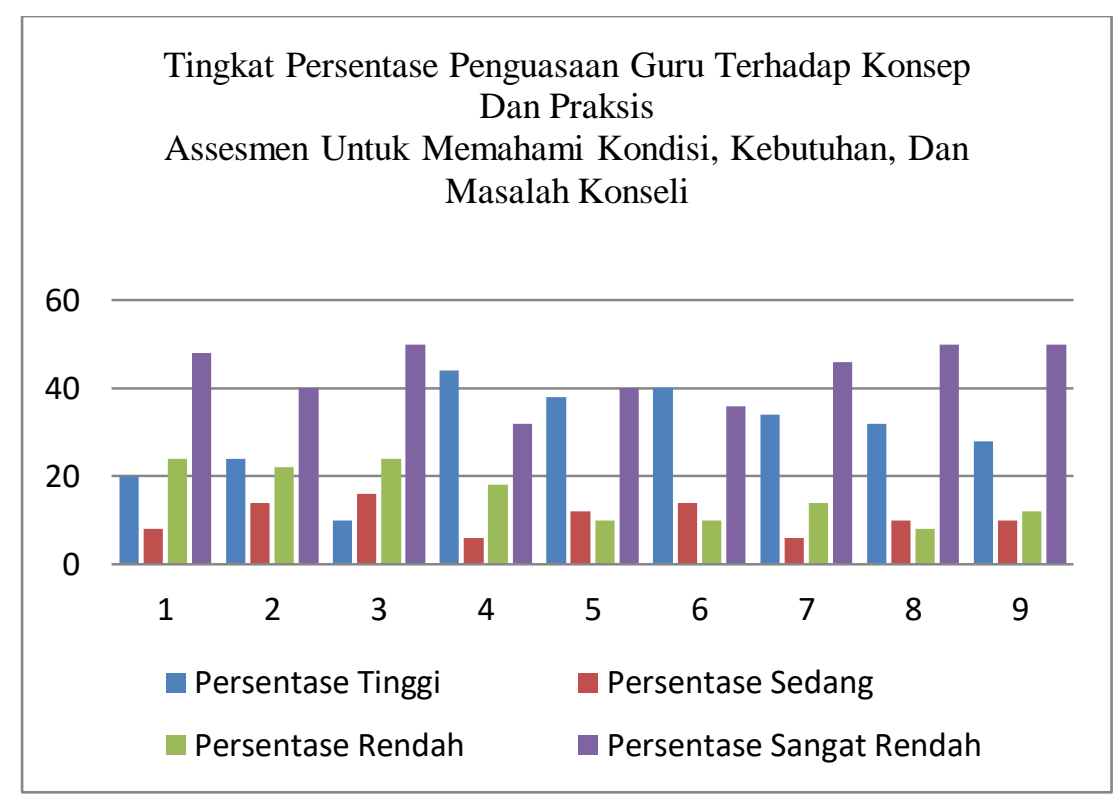

Gambar 2. Penguasaan Guru Terhadap Konsep dan Praksis Assesmen Untuk Memahami Kondisi, Kebutuhan, dan Masalah Konseli

Diagram batang tersebut menjelaskan bahwa tingkat kesulitan Guru BK dalam memahami konsep dan praksis assesmen merata kepada ke Sembilan komponen yang berada dalam kategori sangat rendah. Jika diurutkan maka tingkat kesulitan guru untuk memahami konsep dan praksis assesmen dalam secara jelas akan disajikan dalam bentuk diagram chart yang menyajikan data dalam bentuk persentase. 


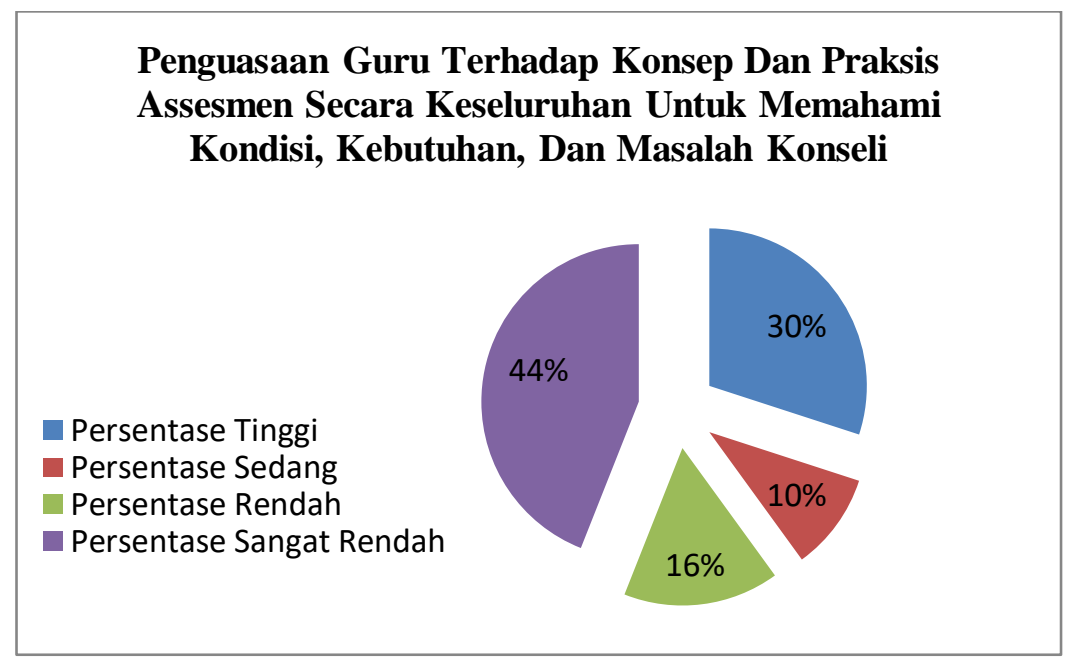

Gambar 3. Persentase Penguasaan Guru Terhadap Konsep Dan Praksis Assesmen Secara Keseluruhan Untuk Memahami Kondisi, Kebutuhan, dan Masalah Konseli

Berdasarkan hasil analisis data di atas, dapat diketahui bahwa penguasaan Guru BK terhadap konsep dan praksis assesmen tergolong sangat rendah. dari 50 orang Guru BK yang tersebar di berbagai Provinsi Lampung, diketahui sebanyak 44\% Guru BK tingkat penguasaan Guru terhadap konsep dan praksis assessment secara keseluruhan untuk memahami kondisi, kebutuhan, dan masalah konseli berada dalam kategori sangat rendah. namun di satu sisi Guru yang menguasai konsep dan praksis assessment secara keseluruhan untuk memahami kondisi, kebutuhan, dan masalah konseli sebanyak 30\%, 16\% untuk kategori tinggi dan 10\% untuk kategori sedang.

Berdasarkan hasil analisis data yang tersebar di Provinsi Lampung tentang “Analisis Tingkat Kesulitan Guru Pembimbing Dalam Menguasai Konsep Dan Praksis Assesment Untuk Memahami Kondisi, Kebutuhan, Dan Masalah Konseli”. Dalam Peraturan Menteri Pendidikan Nasional Nomor 27 tahun 2008 tentang standar kualifikasi akademik dan kompetensi konselor disebutkan bahwa konsep dan praksis asesmen meliputi menguasai hakikat asesmen; memilih teknik asesmen, sesuai dengan kebutuhan pelayanan bimbingan dan konseling; menyusun dan mengembangkan instrumen asesmen untuk keperluan bimbingan dan konseling; mengadministrasikan asesmen untuk mengungkapkan masalah-masalah konseli; memilih dan mengadministrasikan teknik asesmen pengungkapan kemampuan dasar dan kecenderungan pribadi konseli; memilih dan mengadministrasikan instrument untuk mengungkapkan kondisi aktual konseli dalam pelayanan bimbingan dan konseling; 
mengakses data dokumentasi tentang konseli dalam pelayanan bimbingan dan konseling; menggunakan hasil asesmen dalam pelayanan bimbingan dan konseling dengan tepat; dan menampilkan tanggung jawab profesional dalam praktik asesmen.

Konsep dan prkasis asesmen ini sangat penting untuk dipahami oleh guru bimbingan dan konseling. Hal ini dikarenakan tanpa adanya pemahaman yang baik dalam konsep dan praksis asesmen, guru bimbingan dan konseling kurang baik juga dalam melaksanakan program kerja layanan bimbingan dan konseling. Dijelaskan dalam Peraturan Menteri Pendidikan dan Kebudayaan nomor 111 tahun 2014 tentang bimbingan dan konseling pada pendidikan dasar dan pendidikan menengah bahwa program kerja layanan bimbingan dan konseling disusun berdasarkan hasil analisis kebutuhan peserta didik atau konseli dalam berbagai aspek perkembangan.

Dari hasil penelitian dengan analisis data kuantitatif menunjukkan bahwa Guru BK yang mengalami kesulitan dalam menguasai konsep dan praktik assessment untuk memahami kebutuhan dan masalah konseli sebanyak. Tingkat 44\%. Kesulitan Guru BK terhadap konsep dan praksis asesmen ini diperkuat dengan adanya jawaban yang diberikan responden. Dari presentase diatas dapat dilihat bahwa tingkat pemahaman guru bimbingan dan konseling terhadap konsep dan praksis asesmen di sekolah rata-rata dalam kategori rendah. Dalam pelaksanaan di lapangan, ada kemungkinankemungkinan yang lebih besar bahwa guru bimbingan dan konseling dalam praksis asesmen dilakukan dengan baik karena memiliki pemahaman terhadap konsep dan praksis asesmen yang sedang, sehingga perlu banyak mempelajari dan memahami konsep dan praksis asesmen dalam Peraturan Menteri Pendidikan Nasional nomor 27 tahun 2008 tentang standar kualifikasi akademik dan kompetensi konselor.

\section{KESIMPULAN}

Setelah dilakukan analisis terhadap hasil penelitian, dapat disimpulkan bahwa hasil penelitian dengan analisis data kuantitatif menunjukkan bahwa tingkat kesulitan Guru dalam menguasai konsep dan praksis asesmen untuk memahami kondisi, kebutuhan, dan masalah konseli berdasarkan pilihan jawaban responden dalam kategori sedang dengan sangat rendah $44 \%$, hasil penelitian dengan analisis data kuantitatif deskriptif menunjukkan bahwa tingkat kesulitan Guru dalam menguasai konsep dan praksis asesmen untuk memahami kondisi, kebutuhan, dan masalah konseli berdasarkan 
jawaban pembenaran responden dalam kategori stinggi dengan presentase $30 \%$. Hipotesis "Tingkat kesulitan Guru Pembimbing dalam menguasai konsep dan praksis asesmen untuk memahami kondisi, kebutuhan, dan masalah konseli dalam berada kategori rendah" terbukti kebenarannya melalui penelitian yang telah dilakukan.

Berdasarkan hasil secara keseluruhan dari penelitian ini, peneliti memberikan beberapa saran, diantaranya:

1. Bagi Kepala Sekolah

Kepala sekolah diharapkan untuk mengaktifkan guru bimbingan dan konseling dalam perkumpulan MGBK (Musyawarah Guru Bimbingandan Konseling) yang diadakan oleh Diknas yang bertujuan untuk menambah wawasan dan pemahaman lebih luas khususnya terkait konsep dan praksis asesmen dalam bimbingan dan konseling.

2. Bagi Konselor/Guru Bimbingan dan Konseling

Bagi konselor atau guru bimbingan dan konseling diharapkan untuk mengikuti pelatihan yang diadakan oleh Diknas dan MGBK (Musyawarah Guru Bimbingan dan Konseling) yang bertujuan untuk meningkatkan pemahaman konselor atau guru bimbingan dan konseling terhadap konsep dan praksis asesmen.

3. Bagi Peneliti selanjutnya

Peneliti selanjutnya dapat mengkaji korelasi antara konsep dan praksis asesmen pada guru bimbingan dan konseling

\section{DAFTAR PUSTAKA}

Asrori, M. (1990). Unjuk Kerja Petugas Bimbingan dalam Melaksanakan Konseling Dikaji dari Latar Belakang Pendidikan dan Iklim Organisasi Sekolahnya (Doctoral dissertation, Tesis).

Cronbach, L. J. (1984). A research worker's treasure chest. Multivariate behavioral research, 19(2-3), 223-240.

Drummond, Robert J. \& Dayle Jones, Karyn. (2006). Assessment Procedures for Counselors and Helping Professionals, New Jersey, Pearson Merrill Prentice Hall.

Lidz, Carol. (2003). Early Childhood Assessment. New Jersey: Jhon Wiley \& Sons. 
Peraturan Menteri Pendidikan dan Kebudayaan Republik Indonesia No. 111 Tahun 2014 Tentang Bimbingan dam Konseling Pada Pendidikan Dasar dan Pendidikan Menengah.

Permendiknas Nomor 27 Tahun 2008 tentang Standar Kualifikasi Akademik dan Kompetensi Konselor.

Suhendi, Hendi. (2008). Persepsi konselor tentang penguasaan kompetensi yang dimilikinya di SMA Negeri Kota Bandung. Skripsi PPB FIP UPI Bandung: tidak diterbitkan.

Sumardi \& Sunaryo. 2006. Penilaian dalam Pembelajaran (Assesment Of Learning).

Supriadi, D., \& Mulyana, R. (2004). Membangun bangsa melalui pendidikan. Remaja Rosdakarya.

Undang-undang No.20 tahun 2003 tentang Sistem Pendidikan Nasional.

Yusuf, S. (2009). Program bimbingan dan konseling di sekolah. Bandung: Rizqi Press. 